\title{
Nicole Reinhardt
}

Voices of Conscience: Royal Confessors and Political Counsel in Seventeenth-Century

Spain and France. Oxford: Oxford University Press, 2016. Pp. 480. Hb, \$110.

This is a challenging, wonderfully learned but difficult book. Its first goal is to show that ideas of conscience and politics and their interrelation never remain the same but undergo change regularly. The seventeenth century stands out as a pivotal moment of this change, and the book is a comparative history of the institutions of the royal confessor and council of conscience during this period in Spain and in France. The general movement of the conscience of the ruler is from a public to a private one, from a persona publica to a persona privata. The sources are richer for Spain than for France because in the former careful archives were kept and the government more structured. Confessors to the king of Spain throughout this period were Dominicans; in France they were Jesuits.

The author develops her theme in five steps. The first she devotes to the explanation of the institutions and ideologies of council. The confessor was a councillor sui generis who dealt with a more secret area than the other councillors and was an expert in moral theology and the science of conscience. The author considers the chapter on the confessor in Robert Bellarmine's De officio principis christiani (Duties of a Christian prince, 1619) to be the most influential treatment of the topic. Bellarmine insisted on the sins of the $p u-$ blica persona. Starting in the 1570 s, probabilism became influential with royal confessors.

Normative frameworks is the topic of the second step. Here the author stresses the importance of the classic Manual de confessores et penitentes (sic) of the Augustinian friar Martín de Azpilcueta which first appeared in $155^{2}$ and saw many editions up to 1603 .

Drawing upon the long Scholastic tradition, Azpilcueta drew up an extensive list of questions to be put to monarchs in confession that included their public sins. Reinhardt discusses at length three of the public sins that were committed in the area of just war, taxation, and appointment to office. These three categories of public sin gradually faded from the concerns of the royal confessor by the middle of the seventeenth century.

In the third step, the author turns to the practice of the council of conscience. This section is dominated by Luis de Aliaga, the confessor of King Philip III from 1608 to 1621, who was the most active of the Spanish confessors and who receives the most attention in the book after Nicolas Caussin-Jesuit confessor to King Louis XIII. Reinhardt sees him as a regalist, as were many royal confessors, and she looks first at his role in the distribution of offices. He did not see the crisis of $1618 / 19$ that initiated the Thirty Years' War in central 
Europe as the outbreak of a religious war. The author then turns to a long case study on Aliaga's role in the decision to expel the Moriscos in 1612. The section ends with a discussion of the relationship between favorites and confessors who often were rivals and with a look at the relationship between Cardinal Richelieu and the Jesuit Caussin who at the instance of Richelieu became confessor of Louis XIII in early 1637 but was then dismissed by the cardinal in December of that year. This leads into the fourth section that takes up the selfreflection of confessors on their role and features Caussin.

Caussin had published in 1624 a mammoth volume entitled La cour saincte (The holy court) which attempted to show how an individual could live a full Christian life at court and which went through numerous editions and translations during the next forty years. He reverted to an older style of confessor and challenged the king on two major policies: the support of Protestant states in the Thirty Years' War and the oppression of the peasants by the taxes levied on them to pay for the the war. This came to an attack on Richelieu who then saw to his exile to Quimper, a town on the coast of Brittany. He was a throwback to the Scholastic authors of the previous century. After the death of Richelieu and Louis XIII, he returned to Paris. There in 1646 and 1647, he published revised editions of the La cour saincte in which he represented the confessor as a prophet in the style of Isaiah and Ezekiel and then as Seneca in his role as councillor to Nero. The confessor was called to be a prophet. Tomás Carbonell, a Spanish Carmelite, twice met a similar fate in Madrid when he invoked the example of Caussin.

The final step in the evolution of the royal confessor began in the 1640 s in France. It was led by the various long-time enemies of the Jesuits: the early Jansenists, parlement, and the assembly of the clergy all of whom claimed to exercise the role of councilor of conscience. There now set in a turn away from the probabilism generally associated with the Jesuits toward a more rigorous moral theology. Pascal's Provincial Letters of 1656 proved to be an effective weapon against the Jesuits. The long-time Jesuit confessors of Louis XIV, Père François Annat and Père François La Chaise were widely thought to be laxists who failed to restrain the king's sexual appetite and especially his desire for glory on the battlefield and his pursuit of conquest. Gradually there eroded the influence of the confessor in France and his function deconstructed. In an absolute monarchy, the king, it was believed, provided he had a well formed conscience, could make political decisions on his own without the assistance of a confessor. The confessor came to be restricted to the king's private life and to ecclesiastical affairs; his brief did not reach to political sins. So there opened up a divide between the public and the private persona of the king which pointed toward the secularization of politics. In Spain, the role of the confessor 
was challenged theologically and by popular opinion if not to the same degree; the adequacy of theological opinion for issues of politics was questioned.

This is clearly a significant volume that initiates the study of the institution of the royal confessor and council of conscience in the long seventeenth century. Not surprisingly, its importance was at its height during the Thirty Years' War, a fact that the author might have brought out more clearly as well as its part in the Catholic Reform. The author exaggerates the influence of Bellarmine's remarks about the royal confessor in his Duties of a Christian Prince. More important for the role of the confessor was the Instruction on the Confessors of Princes (1608) of Claudio Acquaviva, the Jesuit superior general even though it was somewhat ambiguous and was never published. One might also have expected some treatment of the efforts of the French confessors to reconcile Louis XIII and his mother, Marie de Medici before and during the ministry of Richelieu.

\section{Robert Bireley, S.J.}

Loyola University Chicago

rbirele@luc.edu

DOI $10.1163 / 22141332-00403007-13$ 